\title{
Phytochemical Screening and In vitro Antioxidant Studies of Fagara Budrunga (Zanthozylum Rhesta) Fruit Extracts
}

\author{
SHOBHA V RUPANAR ${ }^{1}$, DATTATRAYA G NAIK ${ }^{2}$, \\ CHITRA N DANDGE $^{2}$ and SHIRISH S PINGALE ${ }^{1}$
}

${ }^{1}$ Department of Chemistry, Baburaoji Gholap College, Pune- 411027, Maharashtra, India

${ }^{2}$ Agharkar Research Institute, Pune-411004, Maharashtra, India

Shobha.rupanar@gmail.com

Receivd 19 March 2016 / Accepted 14 April 2016

\begin{abstract}
Fruits of Fagara budrunga was extracted with solvents of different polarities. Antioxidant activity of $n$-hexane, ethyl acetate and methanol extracts were determined in vitro by DPPH free radical scavenging assay, $\beta$-carotene bleaching assay and reducing power assays. BHT was used as the standard. The radical scavenging activity and reducing power of the extracts significantly decreased in the order methanol extract $>$ ethyl acetate extract $>n$-hexane extract. A strong inhibition of lipid peroxidation in $\beta$-carotene bleaching assay was exhibited by $n$-hexane extract followed by ethyl acetate extract and methanol extract. The methanol extract was found to possess highest phenolic content (75 mg GAE/g dry weight) among the extracts. It is seen that the yield and activities of extract was affected by the solvent used for extraction. Phytochemical investigation of the extracts indicated the presence of alkaloids, flavonoids, tannins, steroids and terpenoids. The present study provides phytochemical screening results and evaluation of antioxidant activities of $F$. budrunga extracts.
\end{abstract}

Keywords: Phytochemical studies, Antioxidant, Fagara budrunga, Mullilam

\section{Introduction}

Free radicals (FR) are often generated as byproducts of various biological reactions. They are involved in many disorders like neurodegenerative diseases, cancer and various inflammatory diseases ${ }^{1}$. Low level of antioxidants and increased production of free radicals cause the oxidative stress ${ }^{2}$ which is responsible for a number of human diseases. Antioxidants are useful for scavenging these reactive oxygen species, eventually controlling the diseases caused by oxidative stress. Several herbs and spices including rosemary, sage, thyme, nutmeg, whit pepper, chili pepper, turmeric, ginger and Chinese medicinal plant extracts have been reported to exhibit antioxidant activity ${ }^{3}$. Literature survey indicates that, there has been a great interest in screening various plant extracts and essential oil for natural antioxidants in recent past ${ }^{4-6}$. Use of natural antioxidants from wine, tea, vegetables and spices are known to be exploited commercially as nutritional supplements ${ }^{7}$. Exploration of 
natural antioxidant compounds of plant extracts helps to develop new molecules as antioxidant. Novel and safe sources of food antioxidants need to be explored ${ }^{8}$. Spices and vegetables possess antioxidant activity that can be applied for preservation of lipids and reduce lipid peroxidation in biological systems ${ }^{9}$. The synthetic antioxidants like BHT and BHA are associated with several side effects on human health ${ }^{10,11}$. Therefore investigation on identifying naturally effective antioxidants is field of active interest ${ }^{12,13}$. Spices are dietary constituents consumed routinely to enhance the flavour of human food ${ }^{14}$.

The spice, Fagara budrunga (Zanthozylunm rhesta, Zanthozylunm budrunga, FamilyRutaceae) is an Indian medicinal plant commonly known as Mullilam. The fruit is solitary, 6 to $8 \mathrm{~mm}$ in diameter finely tubercles and red when ripe. The seeds taste like black pepper and are used as condiments. The whole fruit has stimulant, astringent, aromatic and digestive properties and it is prescribed in urinary diseases ${ }^{15}$. The stem bark and the leaves of the plant have been evaluated for their antibacterial, antifungal and cytotoxic activity ${ }^{16}$. The terpenes from the bark of plant have cytotoxic activity ${ }^{17}$. The alkaloids and ligans from this plant have antimicrobial activity ${ }^{18}$. The total fruit extract of the plant has honeybee attractant activity towards A. cerana $^{19}$. The fruit extract is also found to possess CNS depressant activity ${ }^{20}$. Several chemical constituents including flavanones, alkaloids and esters are reported from $F$. budrunga plant ${ }^{21-28}$. Antinociceptive and antidirrhoeal activity of the plant is reported ${ }^{28}$. The essential oil of this plant is mainly called as mullilum oil. It is known to posses larvicidal ${ }^{29}$, antibacterial $^{30}$ and anti-inflammatory ${ }^{31}$ activities. However literature search indicates that the antioxidant properties of the solvent extracts of $F$. budrunga fruit, is hitherto unknown.

In view of the therapeutic properties attributed to this plant and of potential of spices to yield antioxidant formulations, the phytochemical studies and in vitro antioxidant screening of $n$-hexane, ethyl acetate and methanolic extract of $F$. budrunga fruits were carried out.

\section{Experimental}

\section{Plant material}

F. budrunga fruits were collected from market in March 2014. The plant material was duly authenticated by Botanical Survey of India (BSI), Pune. The material has been deposited at herbarium of BSI (Voucher No. SVS-2/783).

\section{Chemicals}

Butylated hydroxy toluene (BHT) and Tween-20 were purchased from Loba Chemicals, Linoleic acid was purchased from SRL and $\beta$-Carotene from HIMEDIA, Folin-Ciocalteu reagent was purchased from Qualigens. All these are Indian companies. 2, 2-Diphenyl-1picrylhydrazyl (DPPH), Trichloroacetic acid (TCA) was purchased from Fluka, USA. All the solvents used were of analytical grade.

\section{Extraction of $n$-hexane, ethyl acetate and methanolic extracts}

The air dried and powered fruits (500 g) of $F$. budrunga were successively extracted with $n$-hexane $(3 \times 1 \mathrm{~L})$, ethyl acetate $(3 \times 1 \mathrm{~L})$ and methanol $(3 \times 1 \mathrm{~L})$ for $24 \mathrm{~h}$. at room temperature. The solvents were evaporated under reduced pressure to obtain the extractives. Each extractive was investigated independently for antioxidant properties.

\section{Phytochemical screening of the plant extracts}

Each of $n$-hexane, ethyl acetate and methanol extractives $(1 \mathrm{~g})$ of $F$. budrunga fruit was dissolved in own mother solvents $(100 \mathrm{~mL})$ to obtain stocks of concentration $1 \%(\mathrm{w} / \mathrm{v})$. The extracts thus obtained were subjected to phytochemical screening using standard procedures ${ }^{32}$. 


\section{Test for alkaloids}

Hydrochloric acid $(2 \mathrm{~mL})$ was added to the standard solutions of the extractives $(5 \mathrm{~mL})$ and modified Dragandroffs reagent ${ }^{33}(1 \mathrm{~mL})$ was slowly poured in the mixture. Formation of orange or red precipitate indicates the presence of alkaloids.

\section{Test for flavonoids}

Dilute ammonia solution $(5 \mathrm{~mL})$ was added to a portion of the plant extracts $(2 \mathrm{~mL})$ followed by addition of concentrated sulfuric acid. A yellow coloration observed in the extract indicates the presence of flavonoids. The yellow colour disappears on standing.

\section{Test for tannins}

The plant extract $(5 \mathrm{~mL})$ was added to the ferric chloride solution $(0.1 \%)$. Appearance of blue black or brownish green coloration indicates the presence of tannins.

\section{Test for steroids}

Acetic anhydride $(2 \mathrm{~mL})$ was added to plant extract $(5 \mathrm{~mL})$ with sulfuric acid $(2 \mathrm{~mL})$. The colour changed from violet to blue or green in samples indicates the presence of steroids.

\section{Test for terpenoids}

The plant extract $(5 \mathrm{~mL})$ was mixed in chloroform $(2 \mathrm{~mL})$ and concentrated sulphuric acid ( $3 \mathrm{~mL}$ ) was carefully added to form layer. A reddish brown coloration of the interface was formed indicates the presence of terpenoids.

\section{Test for saponins}

The plant extract was diluted with distilled water $(20 \mathrm{~mL})$ and it was agitated in a graduated cylinder for $15 \mathrm{~min}$. The formation of $1 \mathrm{~cm}$ layer of foam showed the presence of saponins.

\section{Antioxidant activity}

\section{$D P P H$ radical scavenging assay by $I C_{50}$ method}

The assay was carried out by reported procedure ${ }^{34}$. A solution $(0.025 \mathrm{~mm})$ of DPPH in methanol was prepared. The solutions of BHT and test sample of various concentrations were prepared in methanol $(0.2 \mathrm{mg}-3.5 \mathrm{mg} / \mathrm{mL})$. DPPH solution without test samples was used as control. The blank was prepared without DPPH. To the test solution (1 mL), DPPH $(1 \mathrm{~mL})$ was added. The solution was allowed to stand at room temperature for $30 \mathrm{~min}$. The decrease in color of the solution was measured spectrophotometrically at $517 \mathrm{~nm}$. The percentage of inhibition was calculated as follows. The experiment was run in triplicates. The $\%$ inhibition was calculated as follows;

$$
\% \text { Inhibition }=\left[A_{c}-\left(A_{t}-A_{b}\right) / A_{c}\right] \times 100
$$

Where $A_{c}$ is the absorbance of control, $A_{b}$ is the absorbance of blank and $A_{t}$ is the absorbance of test Antioxidant activity of the extracts were expressed as $\mathrm{IC}_{50}$ values. The $\mathrm{IC}_{50}$ value is defined as that concentration of sample which inhibits $50 \%$ of DPPH radicals. All the experiments were performed in triplicates.

\section{Reducing power assay}

The assay was carried out by reported procedure ${ }^{35}$. The solutions of extractives (1 $\mathrm{mg} / \mathrm{mL}$ each in methanol) were mixed with phosphate buffer $(0.2 \mathrm{M}, \mathrm{PH} 6.6,1 \mathrm{~mL})$ and potassium ferricyanide $(0.1 \%, 1 \mathrm{~mL})$. The mixture was incubated at $50{ }^{\circ} \mathrm{C}$ for $30 \mathrm{mins}$. 
Aqueous trichloroacetic acid $(10 \%, 1 \mathrm{~mL})$ was added to the mixture and then centrifuged at $3000 \mathrm{rpm}$ for $10 \mathrm{~min}$. To the supernatant solution ferric chloride $(1 \%, 2.5 \mathrm{~mL})$ was added and absorbance was measured at $700 \mathrm{~nm}$. BHT was used as a standard. All the experiments were performed in triplicates.

\section{$\beta$-Carotene linoleic acid assay}

The assay was carried out by reported procedure ${ }^{34}$. To the chloroform solution $(1 \mathrm{~mL})$, $\beta$-carotene $(3.34 \mathrm{mg})$, linoleic acid $(40 \mathrm{mg})$ and Tween-20 (400 mg) were added. The chloroform was then removed at $40{ }^{\circ} \mathrm{C}$ under vacuum using a rotary evaporator. The resulting mixture was diluted with distilled water $(10 \mathrm{~mL})$. The volume of resulting emulsion was further made up to $100 \mathrm{~mL}$ with hydrogen peroxide $(0.01 \mathrm{M})$. The test solutions of each sample $(0.5 \mathrm{mg} / \mathrm{mL}$ and $1 \mathrm{mg} / \mathrm{mL})$ and the standard solutions of BHA and BHT $(1 \mathrm{mg} / \mathrm{mL})$ in methanol were prepared. Aliquots $(2 \mathrm{~mL})$ of the $\beta$-carotene linoleic acid emulsion were transferred into test tubes containing test solutions $(0.1 \mathrm{~mL})$ and standards $(0.1 \mathrm{~mL})$ in methanol A solution containing methanol $(0.1 \mathrm{~mL})$ and $\beta$-carotene linoleic acid emulsion $(2 \mathrm{~mL})$ was used as a control. The blank was prepared in the same manner as that of test solution without $\beta$-carotene- linoleic acid emulsion. The test tubes were placed in water bath maintained at $40{ }^{\circ} \mathrm{C}$. Absorbance of all the samples at $470 \mathrm{~nm}$ were recorded at zero time and after every 15 mins till the colour of $\beta$-carotene disappeared (90 mins.) in the control. The \% inhibition was determined by the following equation:

$$
\% \text { Inhibition }=\left[\left(\mathrm{A}_{\mathrm{A}(90)}-\mathrm{A}_{\mathrm{C}(90)}\right) /\left(\mathrm{A}_{\mathrm{c}(0)}-\mathrm{A}_{\mathrm{C}(90)}\right)\right] \times 100
$$

Where, $\mathrm{A}_{\mathrm{A}(9))}$ is the absorbance of antioxidants at 90 mins, $\mathrm{A}_{\mathrm{C}(90)}$ is the absorbance of control at $90 \mathrm{mins}, \mathrm{A}_{\mathrm{c}(0)}$ is the absorbance of control at $0 \mathrm{~min}$. All the experiments were performed in triplicates.

\section{Total phenolic content}

The total phenolic content was determined by the reported method ${ }^{34}$ using Folin-Ciocalteau reagent. A solution of the sample in methanol $(1 \mathrm{mg} / \mathrm{mL})$ was prepared. To this solution $(1 \mathrm{~mL})$, Folin-Ciocalteau reagent (1/10 dilution, $1 \mathrm{~mL})$ was added. After $5 \mathrm{~min}$., sodium carbonate $(10 \mathrm{~mL}, 7 \%)$ was added to the mixture. This solution was diluted to $25 \mathrm{~mL}$ using distilled water. The absorbance was measured at $750 \mathrm{~nm}$ after incubation for $90 \mathrm{~min}$ at room temperature. Total phenolic content of the samples are expressed as Gallic acid equivalent (GAE) / mg dry weight of the sample. All the experiments were performed in triplicates.

\section{Results and Discussion}

\section{Yields}

The dried and powdered fruits of $F$. budrunga yielded from $n$-hexane (34.5 g, 6.9\%), ethyl acetate $(86 \mathrm{~g}, 17.12 \%)$ and methanol $(100 \mathrm{~g}, 20 \%)$ as dark colored sticky matter.

\section{Phytochemical screening of extracts}

The results obtained in the present investigation are summarized in Table 1. Phytochemical screening reveals the presence alkaloids and flavonides in methanol extract. Ethyl acetate extracts contains all classes of phytochemicals except saponins. The secondary metabolites belonging to tannins, terpenoids and steroids are found to be present in $n$-hexane extracts. Saponins were absent in all the three extracts. 
Table 1. Phytochemical screening of $n$-Hexane, ethyl acetate and methanol extracts of $F$. budrunga Fruit

\begin{tabular}{ccccc}
\hline S. No & Phytochemical & Hexane extract & $\begin{array}{c}\text { Ethyl acetate } \\
\text { extract }\end{array}$ & $\begin{array}{c}\text { Methanol } \\
\text { extract }\end{array}$ \\
\hline 1 & Alkaloids & - & + & + \\
2 & Flavonoids & - & + & + \\
3 & Tannins & + & + & - \\
4 & Steroids & + & + & + \\
5 & Terpenoids & + & + & - \\
6 & Saponins & - & - & - \\
\hline
\end{tabular}

\section{Antioxidant activity}

+ indicate Present, - indicate Absent

In the presents study three antioxidant methods were carried used to evaluate the free radical scavenging and hydrogen donating capacity of each of the $F$. budrunga fruit extracts.

\section{DPPH assay}

This assay is based on electron-donating capacity of antioxidants to quench the free DPPH radicals. The decrease in the colour of DPPH solution due to presence of antioxidants is measured by spectrophotometer at $517 \mathrm{~nm}$. Free radical scavenging capacity of the extracts measured by DPPH is shown in Table 2 . The free radical scavenging capacity of methanol extract $\left(\mathrm{IC}_{50}=150 \mu \mathrm{g} / \mathrm{mL}\right)$ was superior to that of ethyl acetate extract $(550 \mu \mathrm{g} / \mathrm{mL})$ and hexane extract $(3000 \mu \mathrm{g} / \mathrm{mL})$. Polar extracts are therefore found to show strong radical scavenging capacity than non-polar extract or less polar extracts.

Table 2. Determination of $\mathrm{Ic}_{50}$ Values of Extracts by DPPH Radical Scavenging Assay

\begin{tabular}{ccc}
\hline S. No. & Extracts & $\mathrm{IC}_{50}, \mu \mathrm{g} / \mathrm{mL}$ \\
\hline 1 & BHT (Standard) & 20 \\
2 & Hexane extract & 3000 \\
3 & Ethyl acetate extract & 550 \\
4 & Methanol extract & 150 \\
\hline
\end{tabular}

\section{Reducing power assay}

This assay is based on the principle that the substances which have reduction potential react with potassium ferricyanide $\left(\mathrm{Fe}^{3+}\right)$ to form potassium ferrocyanide $\left(\mathrm{Fe}^{2+}\right)$, which then react with ferric chloride to form ferric ferrous complex that has an absorption maximum at $700 \mathrm{~nm}$. Higher the absorbance, higher is the reducing capacity of the extract. The results of the experiments conducted to determine the reducing power of the extract is graphically shown in Figure 1. The methanolic extract shows highest absorbance at $700 \mathrm{~nm}$ compared to other samples thereby indicating strongest reducing capacity among the test samples. The absorbance indicative of reducing power decreases in the order, methanolic extract $(83.50 \%)$ $>$ ethyl acetate extract $(73.92 \%)>n$-hexane extract $(58.47 \%)$. It is noteworthy that activity observed is the same as that observed in DPPH assay.

\section{$\beta$-Carotene linoleic acid assay}

The $\beta$-carotene bleaching assay is based on the spectrophotometric quantification of the decrease in the yellow colour of $\beta$-carotene due to its reaction with the radicals that are generated by linoleic oxidation in an emulsion. The plot of inhibition of lipid peroxidation by the $n$-hexane, ethyl acetate and methanol extract of $F$. budrunga fruits compared with the 
standard, BHT, is shown in Figure 2. In the $\beta$-carotene bleaching assay, the control shows decrease in the absorbance with time due to the formation of peroxides, in absence of antioxidants. The standard and test solution of extracts exhibited slight decrease in absorbance indicating inhibition of peroxides. Per cent inhibition of peroxides at two different concentrations is shown in Table 3. A moderate activity is shown by $n$-hexane and ethyl acetate extracts whereas the activity of methanolic extract is found to still lower at $1 \mathrm{mg} / \mathrm{mL}$.

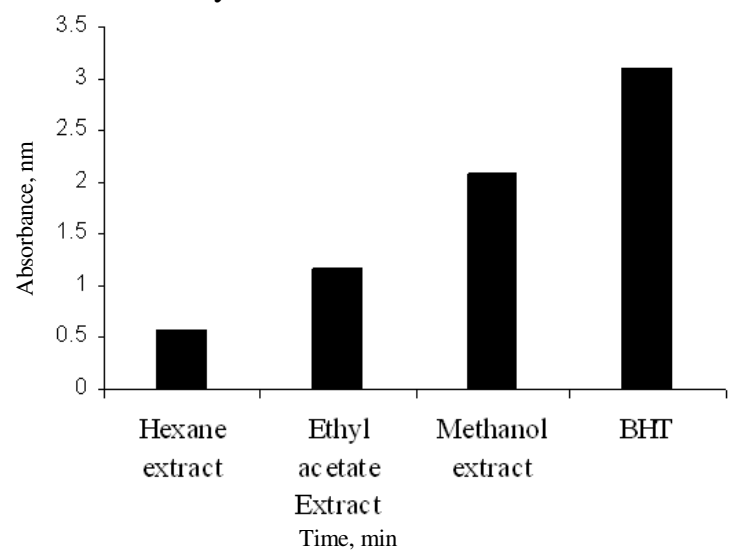

Figure 1. Reducing Power assay of extracts of Fagara budrunga

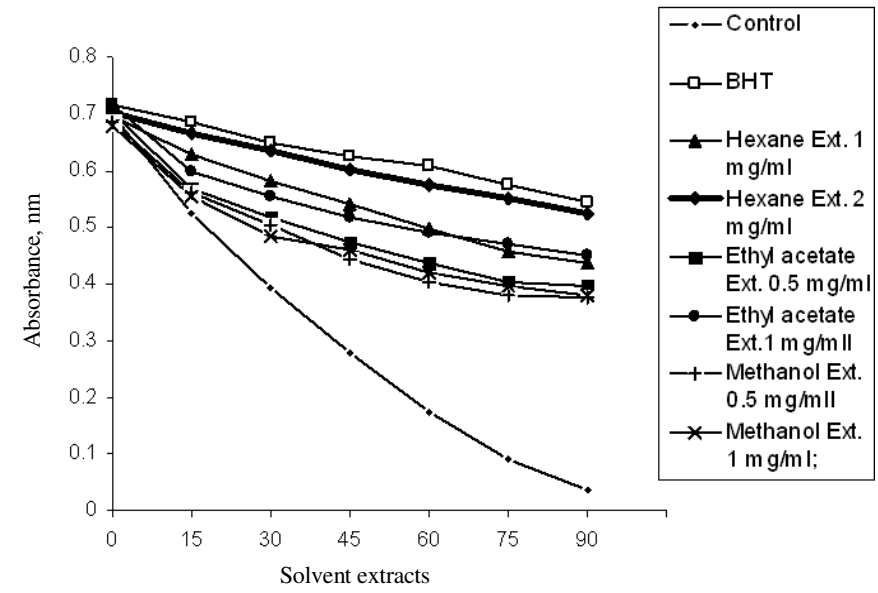

Figure 2. Lipid peroxidation assay of extracts of Fagara budrunga

Table 3. Determination of antioxidant activity of the extracts from $F$. budrunga Fruit by $\beta$ - carotene linoleic acid assay

\begin{tabular}{clc}
\hline S. No. & \multicolumn{1}{c}{ Extracts } & \% Inhibition \\
\hline 1 & BHT, $0.1 \mathrm{mg} / \mathrm{mL}$ & 80.34 \\
2 & Hexane extract, $1 \mathrm{mg} / \mathrm{mL}$ & 66.24 \\
3 & Hexane extract, $2 \mathrm{mg} / \mathrm{mL}$ & 77.17 \\
4 & Ethyl acetate extract, $0.5 \mathrm{mg} / \mathrm{mL}$ & 56.57 \\
5 & Ethyl acetate extract, $1 \mathrm{mg} / \mathrm{mL}$ & 65.29 \\
6 & Methanol extract, $0.5 \mathrm{mg} / \mathrm{mL}$ & 53.74 \\
7 & Methanol extracts, $1 \mathrm{mg} / \mathrm{mL}$ & 54.35 \\
\hline
\end{tabular}




\section{Total phenolic content}

This assay measures the reducing capacity of the substance. The methanolic extract indicated highest total phenolic content ( $75 \mathrm{mg} \mathrm{GAE} / \mathrm{g}$ dry weight) among the test samples followed by ethyl acetate extract (40 mg GAE/g dry weight) and n-hexane extract (27 mg GAE/g dry weight). The methanolic extract possesses strong reducing capacity as compared to ethyl acetate and $n$-hexane extract. This is also supported by DPPH and reducing power assays.

Several studies have reported the relationship between antioxidant capacity and polyphenolic compounds ${ }^{36-39}$. The polyphenols are extracted from plants by polar solvents. The extracts obtained by using polar solvents are therefore expected to exhibit better antioxidant activity than those obtained using less polar solvents or non polar solvents. This is also supported by the report from the literature ${ }^{40}$. Presence of phenolics in food is particularly important for their oxidative stability and antimicrobial protection ${ }^{41}$. A phenolic compound, Xanthoxylin, reported in the polar extract of $F$. budrunga $a^{41}$ could be one of the compounds responsible for better antioxidant activity of methanolic extract as compared to other extracts.

\section{Conclusion}

The present study gives the fundamental information on the antioxidant activities of Fagara budrunga fruit extracts. The crude extracts obtained from all the solvents showed satisfactory inhibition of peroxide and free radical scavenging activity. Among all the extracts, the methanol extract exhibited the highest free radical scavenging activity. On the basis of the results it is suggested that $F$. budrunga fruit could be used as source of natural antioxidant drugs.

\section{Acknowledgement}

The authors wish to thanks, Department of Biotechnology (DBT), New Delhi, India and Principal of B.G. College, Pune for support of this study.

\section{References}

1. Ames B N, Shigenaga M K and Hagen T M, Proc Natl Acad Sci U.S.A, 1993, 90(17), 7915-7922.

2. Cerutti P A, Lancet, 1994, 344(8926), 862-863; DOI:10.1016/S0140-6736(94)92832-0

3. Lee S E, Hwang H J and Ha J S, Life Sci., 2003, 73(2), 167-179; DOI:10.1016/S00243205(03)00259-5

4. Baratta M T, Dorman J D, Deans S G, Binodi D M and Ruberto G, J Ess Oil Res., 1998, 10(6), 618-627; DOI:10.1080/10412905.1998.9700989

5. Lee K G and Shibamoto T, J Agric Food Chem., 2002, 50(17), 4947-4952; DOI:10.1021/jf0255681

6. Meena M R and Sethi V, J Food Sci Technol., 1994, 31, 68-70.

7. Schuler P, In: Hudson B J F (Eds.), London: Elsevier, 1990, 99-170.

8. Kahkonen M P, Hopia A I, Vuorela H J, Rauha J, Pihlaja K, Kujala T S and Heinonen M, J Agric Food Chem., 1999, 47(10), 3954-3962; DOI:10.1021/jf9901461

9. Couladis M, Tzakou O, Harvala C and Verykokidou E, J Phytother Res., 2003, 17, 194-195.

10. Bronen A L, J Am Oil Chem Soc., 1975, 52, 59; DOI:10.1007/BF02901825

11. Ito N, Fukushima S A, Hasegawa, Shibata M and Ogiso T, J Natl Cancer Inst., 1983, 70, 343-344.

12. Chang S S, Ostic-matijasavic B, Hsieh O A L and Hunang C L, J Food Sci., 1977, 42(4), 1102-1106; DOI:10.1111/j.1365-2621.1977.tb12676.x

13. Shobana S and Naidu K A, PLEFA, 2008, 62, 107-110; DOI:10.1054/plef.1999.0128 
14. Kochhar K P, Indian J Physiol Pharmacol, 2008, 52(2), 106-122.

15. Qudrat-I-Khuda M, Qazi A K M and Haq N, J Sci Ind Res, 1960, 3, 4-5.

16. Chadha Y R, The Wealth of India, Raw Materials, Vol.11, CSIR Publications, New Delhi, 1976, 21-25.

17. Sayeed A, Bhuiyan M S, Mosaddik M A, Islam M A and Astaq Mondal Khan G R, Fitoterapia, 2001, 72, 428-430; DOI:10.1016/S0367-326X(00)00336-1

18. Rahman M, Mukhlesur, Gray, Alexander I Khondkar, Proma I and Anwarul M, Nat Prod Comm., 2008, 3, 45-47.

19. Naik D G, Banhatti P, Chawda S S and Thomas D, J Apic Res., 2003, 42, 48-49.

20. Naik D G, Katke S, Banhatti P and Natu A D, Ind J Chem., 1999, 38B, 122-124.

21. Shetgiri N P and Rege L N, Ind J Chem., 2003, 42B, 648-650.

22. Ahmad M U, Rahman M A, Huq E and Chowdhury R, Fitoterapia, 2003, 74(1-2), 91-193; DOI:10.1016/S0367-326X(02)00286-1

23. Shetgiri N P and Rege L N, Asian J Chem., 1998, 10(4), 848-851.

24. Banerjee H, Pal S and Adityachaudhury N, Planta Med., 1989, 55, 403.

25. Joshi B S, Puar M S, Moore K M and Pelletier S W, Heterocycles, 1991, 32(7), 13651370; DOI:10.3987/COM-91-5758

26. Thappa R K, Dhar K L and Atal C K, Phytochem, 1976, 15(10), 1568-1569; DOI:10.1016/S0031-9422(00)88942-6

27. Khastagir H, Curr Sci., 1947, 16(6), 185.

28. Rahaman M T, Alimuzzaman M, Ahamad S and Chowdhury A A, Fitoterapia, 2002, 73(4), 340-342; DOI:10.1016/S0367-326X(02)00083-7

29. Pitasawat B, Champakaew D, Choochote W, Jitpakdi A, Chaithong U, Kanjanapothi D, Rattanachanpichai E, Tippawangkosol P, Riyong D, Tuetun B and Chaiyasit D, Fitoterapia, 2007, 78(3), 205-210; DOI:10.1016/j.fitote.2007.01.003

30. Wannissorn B, Jarikasem S, Siriwangchai T and Thubthimthed S, Fitoterapia, 2005, 76(2), 233-236; DOI:10.1016/j.fitote.2004.12.009

31. Abraham G J S and Agshikar N V, Pharmacol., 1972, 7, 109; DOI:10.1159/000136279

32. Chandrapa C P, Shilpashree C B, Karthik M R, Govindappa M and Sandananda T S, J Phyt., 2011, 3(1), 26-32.

33. Tandon N, Appendix I, Matrials and Methods, In: Tandon N, (Eds.), Vol. 1, ICMR, New Delhi, 2010, pp 341.

34. Dattatraya G Naik, Chitra N Dandge and Shobha V Rupanar, J Ess Oil Res., 2011, 23(3), 12-19; DOI:10.1080/10412905.2011.9700451

35. Hossein A, Barzegar M and Mohammad A S, Food Chem., 2004, 92(3), 521-525; DOI:10.1016/j.foodchem.2004.08.020

36. Yasoubi P, Barzegar1 M, Sahari M A and Azizi M H, J Agric Sci Technol., 2007, 9(1), 35-42.

37. Wojdyło A, Jan O S and Czemerys R, Food Chem., 2007, 105(3), 940-949; DOI:10.1016/j.foodchem.2007.04.038

38. Soheila M and Mahmood R M, J Med Plants Res., 2010, 4(7), 517-521; DOI:10.5897/JMPR10.292

39. Nagendra P K, Chew E, Hock K, Kin W K and Amin I, J Biomed Biotechnol, 2010 Article ID 871379, DOI:10.1155/2010/871379

40. Marinova D, Ribarova F and Atanassova M, Univ Chem Technol Metallurgy, 2005, 40(3), 255-260.

41. Anastasia D, Maya M and Kontogiorgis C A, Biorg Med Chem., 2009, 17(23), 80738075; DOI:10.1016/j.bmc.2009.10.002 